\title{
ANALISIS SISTEM DISTRIBUSI PRODUKSI AIR DAN STRATEGI UNTUK PENURUNAN LOSSES PADA PDAM TIRTA MEULABOH KABUPATEN ACEH BARAT
}

\author{
Fitriadi $^{1)}$, Andi Yusra ${ }^{2)}$ \\ 1) Staf Pengajar Fakultas Teknik UTU \\ 2) Staf Pengajar Fakultas Teknik UTU
}

\begin{abstract}
PDAM Tirta, Meulaboh, West Aceh District, WTP Lapang, is a regional company which gives clean water service to the people of Meaulaboh, West Aceh District. The capacity of production of PDAM Tirta, Meulaboh, West Aceh District WTP Lapang, was 80 liters/second, but during the system of distribution, it lost water at the average of $\pm 47.95 \%$ and the coverage of service of $39.06 \%$. This condition was still under the ideal condition, that is, the loss of $\leq 20$ and the coverage of service was $\geq$ $60 \%$.

The aim of the research was to find the design of increasing the production capacity in order to increase the coverage of service and formulate the strategy to increase the production capacity in water distribution system. Based on the analysis, it could be concluded that the low coverage of service occurred because the people's need for water at Meulaboh increased along with the increase in population. Another factor was the facility of distribution network and the production installation was already old so that a lot of water got lost.

Based on the projection of the number of population, using Geometric Method, it was found that the number of population at Meulaboh in the early of the current year of 2012 was 58,645 and at the end of the current year of 2021 was 71,894 with the level of the growth rate was 2.29\%. The total need for water by the people of Meulaboh in the early current year of 2012 was 5,499,731 liters/day (63.65 liters/second), and at the end of the current year of 2021 was 9,920,712 liters/day (14.82 liters/second) Based on the data analysis, it was found that the increase of the planned production capacity was 115 liters/second. The strategic planning in supporting the increase of the production capacity of PDAM Tirtanadi, Meulaboh, West Aceh District, WTP Lapang was the strategic planning for decreasing the loss of clean water, the developing strategy for clean water supply system., the strategy for increasing production capacity, and the strategy for increasing the quality of water.
\end{abstract}

Keywords: Water Treatment Plan, Production Capacity, Increasing the Capacity, Population Projection

\section{PENDAHULUAN}

Pelayanan air bersih merupakan komponen pelayanan publik yang sangat penting. Air merupakan kebutuhan dasar yang tidak dapat dilepaskan dari kehidupan manusia. Penyediaan air bersih menjadi perhatian khusus setiap negara di dunia tidak terkecuali di Indonesia. Pertumbuhan penduduk, perkembangan pembangunan, dan meningkatnya standar kehidupan menyebabkan kebutuhan akan air bersih terus meningkat. Hal ini menjadikan kualitas layanan perusahaan penyedia dan pengelola air bersih sangat dibutuhkan oleh masyarakat

Agustina D.V., (2007) menyatakan sistem distribusi produksi air dengan perpipaan, kualitas pelayanan tergantung pada kondisi jaringan pipa distribusi air dan kinerja pelayanan. Sedangkan 
kualitas pelayanan pada sistem distribusi produksi air non perpipaan tergantung pada kondisi lingkungan alam sekitarnya.

Saat ini kapasitas produksi terpasang PDAM Tirta Meulaboh WTP Lapang memiliki kapasitas 80 ltr/dtk dengan kapasitas yang dimanfaatkan 70 ltr/dtk. Sumber air yang digunakan bersumber dari air permukaan yaitu sungai. Dari hasil survei didapatkan kondisi bahwa debit aliran kecil (kurang mencukupi), tekanan air kurang, aliran berlangsung secara tidak kontinyu atau jam-jam pengaliran sering tidak menentu sehingga sangat merugikan konsumen. Hal ini terjadi karena terdapat beberapa permasalahan yang timbul dalam proses penyediaan air selama ini salah satunya adalah terjadinya kehilangan air (losses) atau dikenal dengan kebocoran air.

Ferijanto, K., (2007) menyatakan bahwa kehilangan air merupakan faktor yang dapat menyebabkan kerugian pada suatu sistem penyediaan air, baik terhadap PDAM maupun terhadap konsumen. Dengan adanya kehilangan air maka pihak PDAM akan menderita kerugian secara ekonomi dan finansial, sedangkan kerugian yang diderita pihak konsumen adalah terganggunya kapasistas dan kontinuitas pelayanan.

Husen, dkk (2009) menyatakan bahwa ditinjau dari faktor penyebabnya kebocoran pada sistem distribusi, kebocoran dibagi menjadi dua bagian yaitu kebocoran karena faktor teknis dan kebocoran karena faktor nonteknis.

Berdasarkan hasil survey dilokasi penelitian didapat data tingkat kebocoran air pada PDAM Tirta Meulaboh rata-rata 47,95\%.

Tabel 1. Data Produksi dan Kebocoran Air

\begin{tabular}{cccc}
\hline No & Tahun & $\begin{array}{c}\text { Volume Produksi } \\
\left(\mathrm{m}^{3}\right)\end{array}$ & $\begin{array}{c}\text { Persentase } \\
\text { Kebocoran }\end{array}$ \\
\hline 1 & 2011 & 2.387 .428 & 41,38 \\
2 & 2012 & 2.421 .470 & 44,40 \\
3 & 2013 & 2.003 .865 & 44,25 \\
4 & 2014 & 2.280 .940 & 47,95 \\
\hline
\end{tabular}

Sumber: PDAM Tirta Meulaboh Kabupaten Aceh Barat Tahun 2015

Berdasarkan Tabel 1. terlihat bahwa persentase kebocoran PDAM Tirta Meulaboh Kabupaten Aceh Barat selama empat tahun di atas 40 \%. Kondisi kehilangan air yang terjadi masih melebihi standar tingkat kehilangan air minimum yang dizinkan yaitu sebesar 20\%. Berdasarkan hasil survey didapat data persentase cakupan palayanan PDAM Tirta Meulaboh tahun 2011 sampai dengan 2014 adalah sebagai berikut.

Tabel 2. Perbandingan Jumlah Penduduk dan Cakupan Pelayanan

\begin{tabular}{ccccc}
\hline No & Tahun & $\begin{array}{c}\text { Jumlah } \\
\text { Penduduk } \\
\text { (Jiwa) }\end{array}$ & $\begin{array}{c}\text { Penduduk yang } \\
\text { Terlayani } \\
\text { (Jiwa) }\end{array}$ & $\begin{array}{c}\text { Persentase Cakupan } \\
\text { Pelayanan }\end{array}$ \\
\hline 1 & 2011 & 164.360 & 39.268 & 25,62 \\
2 & 2012 & 169.111 & 64.513 & 39,25 \\
3 & 2013 & 173.558 & 49.552 & 29,30 \\
4 & 2014 & 177.532 & 67.796 & 39,06 \\
\hline
\end{tabular}

Sumber: PDAM Tirta Meulaboh Kabupaten Aceh Barat Tahun 2015

Berdasarkan data Tabel 2. di atas dapat disimpulkan bahwa cakupan pelayanan PDAM Tirta Meulaboh Kabupaten Aceh Barat masih relatif rendah jika dibandingkan dengan cakupan pelayanan air untuk masyarakat untuk mendukung program MDGS Tahun 2015 yaitu cakupan pelayanan minimal $60 \%$. 
Di samping permasalahan-permasalahan yang timbul dalam sistem distribusi produksi air, PDAM juga menghadapi tantangan untuk meningkatkan kinerja sistem dalam rangka mengatasi peningkatan konsumsi air masyarakat. Konsumsi air akan selalu mengalami peningkatan seiring dengan pertumbuhan populasi. Sehingga untuk penurunan losess dalam upaya peningkatan pelayanan kepada masyarakat.

\section{KAJIAN LITERATUR}

\subsection{Sistem Distribusi Air Bersih.}

Menurut Damanhuri, E., (1989) sistem distribusi adalah sistem yang langsung berhubungan dengan konsumen, yang mempunyai fungsi pokok mendistribusikan air yang telah memenuhi syarat ke seluruh daerah pelayanan. Sistem ini meliputi unsur sistem perpipaan dan perlengkapannya, hidran kebakaran, tekanan tersedia, sistem pemompaan (bila diperlukan), dan reservoir distribusi.

Sistem distribusi air minum terdiri atas perpipaan, katup-katup, dan pompa yang membawa air yang telah diolah dari instalasi pengolahan menuju pemukiman, perkantoran dan industri yang mengkonsumsi air. Juga termasuk dalam sistem ini adalah fasilitas penampung air yang telah diolah (reservoir distribusi), yang digunakan saat kebutuhan air lebih besar dari suplai instalasi, meter air untuk menentukan banyak air yang digunakan, dan keran kebakaran.

\subsection{Proyeksi Jumlah Penduduk}

Menurut Anonimus (1990), dalam Standar Kriteria Desain Sistem Penyediaan Air Bersih, proyeksi jumlah penduduk di masa yang akan datang dapat diprediksikan berdasarkan laju pertumbuhan penduduk yang direncanakan relatif naik setiap tahunnya. Standar Kriteria Desain Sistem Penyediaan Air Bersih memberi rumusan untuk menghitung proyeksi jumlah penduduk dengan metode Geometrik yaitu:

$$
\mathrm{Pn}=\mathrm{Po}(1+\mathrm{r})^{\mathrm{n}}
$$

Keterangan:

Pn = Jumlah penduduk pada tahun ke $\mathrm{n}$ perencanaan (jiwa).

Po = Jumlah penduduk pada awal tahun perencanaan (jiwa).

$\mathrm{r} \quad=$ Ratio angka pertumbuhan tiap tahun (\%) .

$\mathrm{n} \quad=$ Periode tahun perencanaan.

\subsection{Kebutuhan Air Bersih}

Kebutuhan air bersih adalah banyaknya air yang diperlukan untuk melayani penduduk yang dibagi dalam dua klasifikasi pemakaian air, yaitu untuk keperluan domestik (rumah tangga) dan non domestik. Target pelayanan harus mengacu pada Millenium Development Goals (MDGs) Kabupaten Aceh Barat di mana daerah perkotaan harus sudah terlayani $60 \%$ dari jumlah penduduk. Dalam melayani jumlah cakupan pelayanan penduduk akan air bersih sesuai target, maka direncanakan kapasitas sistem penyediaan air bersih yang dibagi dalam dua klasifikasi pemakaian air, yaitu untuk keperluan domestik (rumah tangga) dan non domestik.

\subsection{Kebutuhan Sistem dan Kapasitas Desain}

Menurut Anonimus (1990) dalam Standar Kriteria Desain Sistem Penyediaan Air Bersih, kapasitas desain adalah kapasitas produksi yang dibutuhkan oleh sistem penyediaan air yang direncanakan terhadap kebutuhan air di daerah perencanaan.

Standar Kriteria Desain Sistem Penyediaan Air Bersih, memberikan rumusan untuk menghitung kapasitas produksi yaitu:

Qprod = Qm + Qh

Keterangan: 
Qprod = Kapasitas produksi (ltr/dt).

$\mathrm{Qm} \quad=$ Kapasitas air hari maksimum (ltr/dt).

Qh $\quad=$ Kehilangan air (ltr/dt).

\subsection{Kehilangan Air}

Menurut Anonimus (1990) dalam Standar Kriteria Desain Sistem Penyediaan Air Bersih, kehilangan air adalah tidak sampainya air yang diproduksi kepada pelanggan atau konsumen. Standar Kriteria Desain Sistem Penyediaan Air Bersih memberikan batasan faktor kehilangan air yang diperbolehkan tidak melebihi angka toleransi sebesar 20\% dari kapasitas debit produksi.

Menurut Djamal, Z., dkk (2009) kehilangan air bersih perpipaan atau air PAM sering disebut sebagai non-revenue-water (NRW), atau ada juga yang menggunakan istilah unacounted for water (UFW) terutama jika komponen air yang sah dipakai atau digunakan oleh pemakai tetapi tidak tertagih (unbilled authorized consumption) dapat diabaikan karena tidak terlalu signifikan besarnya. Sederhananya adalah air bersih hasil olahan yang tidak menjadi pendapatan (revenue) pengelola karena kesalahan pengelolaan dan sebab-sebab lain disebut secara umum sebagai "kebocoran”.

Selanjutnya Djamal, Z., dkk (2009) kehilangan Air (Water Losses) adalah selisih antara jumlah air yang dipasok kedalam jaringan perpipaan air dan jumlah air yang dikonsumsi.

Kehilangan Air = Jumlah Air yang dipasok - Jumlah Air yang dikonsumsi .....

Sedangkan Tingkat Kehilangan Air adalah persentase perbandingan antara kehilangan air dan jumlah air yang dipasok ke dalam jaringan perpipaan air.

Tingkat Kehilangan Air $=\frac{\text { Kehilangan Air }}{\text { Jumlah Air yang Dipasok }} \times 100 \%$

Menurut Richard G., et al (2000) Secara umum, air yang tidak terhitung Unaccounted-For Water (UFW) adalah perbedaan antara air yang dipasok ke sistem distribusi dan air yang meninggalkan sistem melalui penggunaan dimaksud.

Selanjutnya MWAC, (1999) UFW dapat didefinisikan sebagai persentase air yang dihasilkan dari sumber air baku yang tidak diperhitungkan. Sedangkan Yepes, (1995) UFW didefinisikan perbedaan antara air yang diantar ke sistem distribusi dan air yang dijual.

Battermann, A., (2001) Unaccounted-For Water didefinisikan sebagai hilangnya air dihitung sebagai perbedaan antara kuantitas air diumpankan kedalam sistem distribusi (produksi air minum) dan kuantitas air dimanfaatkan dengan sah, yang telah dimeterkan atau dapat diperkirakan. Kuantitas air dimasukkan yang sah belum termasuk pemakaian masyarakat yang tidak dimeterkan.

Menurut Djamal, Z., dkk (2009) kehilangan air atau NRW berbeda dengan Kebocoran Air (Water Leakage). Pengertian kebocoran air dapat dikatakan lebih sempit dari kehilangan air. water leakage, yang diartikan kebocoran air dan biasanya istilah water leakage sering diilustrasikan dengan gambar "pipa bocor". Oleh sebab itu water leakage atau kebocoran air lebih tepat digunakan untuk kehilangan air secara fisik/teknis saja.

Berdasarkan hasil seminar Perpamsi 2005 menyatakan bahwa Air yang Tak Bisa Direkeningkan (ATBD) adalah input sistem dikurangi konsumsi rekening sehingga dapat ditulis persamaan sebagai berikut:

ATBD $=$ Input Sistem - Konsumsi Berekening

\section{METODOLOGI}

\subsection{Tipe Penelitian}

Berdasarkan sifatnya, jenis penelitian ini tergolong ke dalam penelitian deskriptif analitik, yaitu jenis penelitian yang mendeskripsikan pemecahan terhadap masalah yang dihadapi. Dengan adanya 
penelitian ini, diharapkan dapat memberikan solusi yang tepat dalam memecahkan permasalahan yang sedang dihadapi.

\subsection{Tahap Penelitian.}

Tahapan penelitian sebagaimana terdapat pada gambar berikut.

\section{Latar Belakang Masalah}

1. Kehilangan Air masih diatas tingkat kehilangan air minimum yaitu sebesar $20 \%$

2. Cakupan pelayanan masih dibawah cakupan pelayanan minimal yaitu $60 \%$

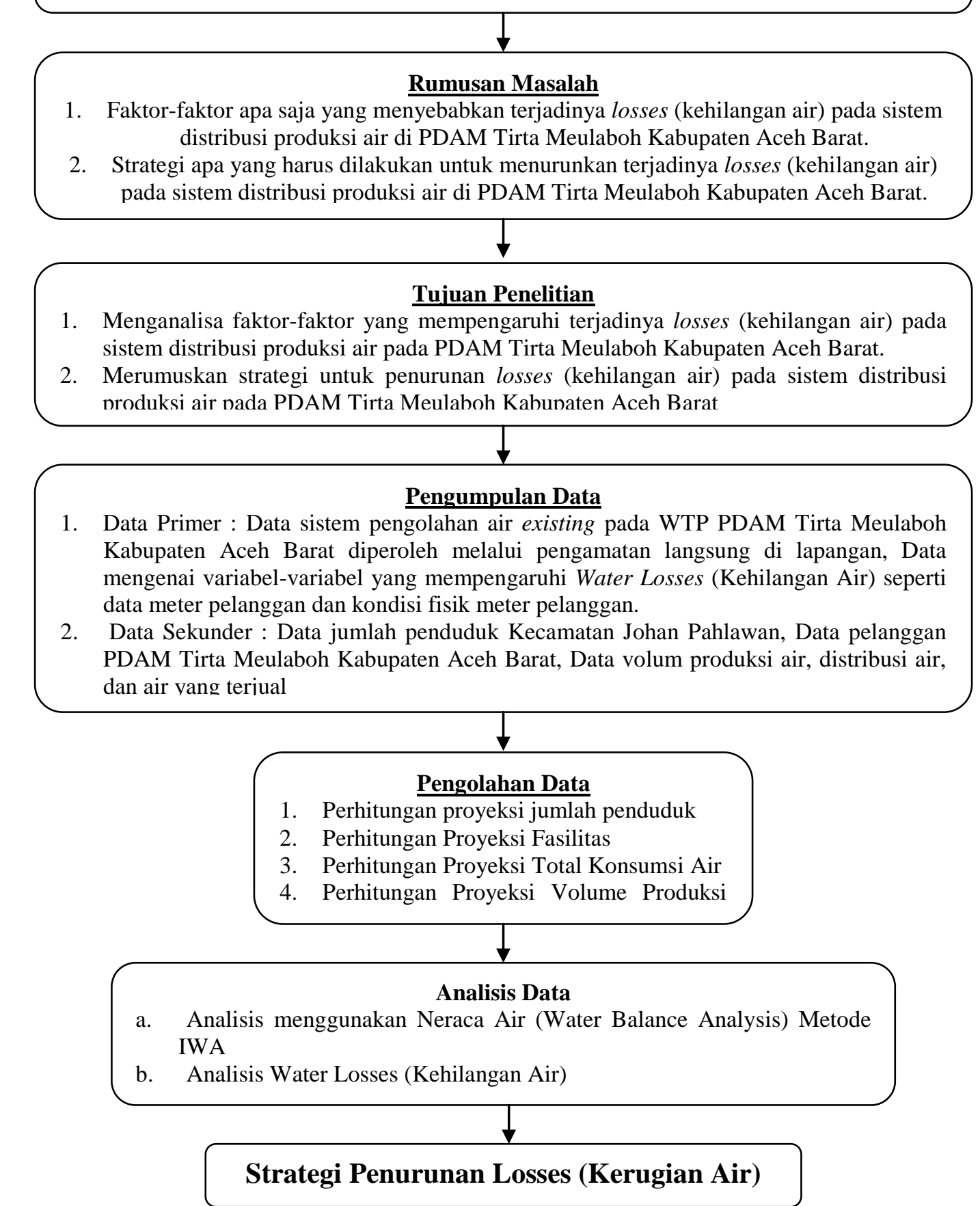

Gambar.1. Flowchart Tahapan Penelitian 


\section{HASIL DAN ANALISIS}

\subsection{Proyeksi Jumlah Penduduk}

Berdasarkan metode geometrik maka dapat dihitung proyeksi jumlah penduduk Kota Meulaboh tahun 2015-2024 seperti hasil yang terdapat pada berikut

Tabel 3. Proyeksi Jumlah Penduduk Kota Meulaboh.

\begin{tabular}{ccc}
\hline Tahun & $\begin{array}{c}\text { Laju Pertumbuhan } \\
\text { Penduduk (\%) }\end{array}$ & $\begin{array}{c}\text { Jumlah Penduduk } \\
\text { (Jiwa) }\end{array}$ \\
\hline 2015 & 2,29 & 58.645 \\
2016 & 2,29 & 59.988 \\
2017 & 2,29 & 61.361 \\
2018 & 2,29 & 62.765 \\
2019 & 2,29 & 64.202 \\
2020 & 2,29 & 65.672 \\
2021 & 2,29 & 67.175 \\
2022 & 2,29 & 68.713 \\
2023 & 2,29 & 70.286 \\
2024 & 2,29 & 71.894 \\
\hline
\end{tabular}

Sumber: Hasil Pengolahan Data (2015).

\subsection{Perhitungan Kebutuhan Air.}

\subsubsection{Kebutuhan Air Domestik.}

Hasil perhitungan besarnya jumlah penduduk terlayani oleh Sambungan Rumah (SR) dan Hidran Umum (HU) dapat dilihat pada tabel berikut

Tabel 4. Jumlah Penduduk Terlayani Tahun 2015 - 2024.

\begin{tabular}{ccccccc}
\hline NO & Tahun & $\begin{array}{c}\text { Jumlah } \\
\text { Penduduk } \\
\text { (Jiwa) }\end{array}$ & $\begin{array}{c}\text { Cakupan } \\
\text { Pelayanan } \\
(\%)\end{array}$ & $\begin{array}{c}\text { Jumlah } \\
\text { Penduduk } \\
\text { Terlayani } \\
\text { (Jiwa) }\end{array}$ & $\begin{array}{c}\text { Sistem Pelayanan } \\
\text { Sambungan } \\
\text { Rumah (SR) } \\
80 \%\end{array}$ & $\begin{array}{c}\text { Hidran } \\
\text { Umum (HU) } \\
20 \%\end{array}$ \\
\hline 1 & 2015 & 58.645 & 40 & 23.458 & 18.767 & 4.692 \\
2 & 2016 & 59.988 & 45 & 26.994 & 21.596 & 5.399 \\
3 & 2017 & 61.361 & 50 & 30.680 & 24.544 & 6.136 \\
4 & 2018 & 62.765 & 55 & 34.521 & 27.617 & 6.904 \\
5 & 2019 & 64.202 & 60 & 38.521 & 30.817 & 7.704 \\
6 & 2020 & 65.672 & 65 & 42.687 & 34.149 & 8.537 \\
7 & 2021 & 67.175 & 70 & 47.023 & 37.618 & 9.405 \\
8 & 2022 & 68.713 & 75 & 51.535 & 41.228 & 10.307 \\
9 & 2023 & 70.286 & 80 & 56.228 & 44.983 & 11.246 \\
10 & 2024 & 71.894 & 85 & 61.110 & 48.888 & 12.222 \\
\hline
\end{tabular}

Sumber: Hasil Pengolahan Data.

Kebutuhan air domistik dapat dilihat pada tabel berikut: 
Tabel 5. Kebutuhan Air Domistik Tahun 2015 - 2024.

\begin{tabular}{ccccc}
\hline NO & Tahun & $\begin{array}{c}\text { Sambungan Rumah } \\
\text { (SR) 90 ltr/hr/org }\end{array}$ & $\begin{array}{c}\text { Hidran Umum } \\
(\text { HU) 30 ltr/hr/org }\end{array}$ & $\begin{array}{c}\text { Total Kebutuhan Air } \\
\text { (ltr/hr) }\end{array}$ \\
\hline 1 & 2015 & 1.688 .987 & 140.749 & 1.829 .735 \\
2 & 2016 & 1.943 .604 & 161.967 & 2.105 .571 \\
3 & 2017 & 2.208 .993 & 184.083 & 2.393 .076 \\
4 & 2018 & 2.485 .513 & 207.126 & 2.692 .639 \\
5 & 2019 & 2.773 .535 & 231.128 & 3.004 .663 \\
6 & 2020 & 3.073 .441 & 256.120 & 3.329 .561 \\
7 & 2021 & 3.385 .623 & 282.135 & 3.667 .758 \\
8 & 2022 & 3.710 .486 & 309.207 & 4.019 .693 \\
9 & 2023 & 4.048 .448 & 337.371 & 4.385 .819 \\
10 & 2024 & 4.399 .938 & 366.662 & 4.766 .600 \\
\hline
\end{tabular}

Sumber: Hasil Pengolahan Data.

4.2.2. Kebutuhan Air Non Domestik.

Kebutuhan air non domestik selama periode perencanaan seperti terdapat pada tabel berikut.

Tabel 6. Kebutuhan Air Non Domistik Tahun 2015 - 2024.

\begin{tabular}{cccc}
\hline NO & Tahun & $\begin{array}{c}\text { Kebutuhan Air Domestik } \\
(\text { Qd) }(\text { ltr/hr) }\end{array}$ & $\begin{array}{c}\text { Kebutuhan Air Non Domestik } \\
\text { (Qnd) }=20 \%(\mathrm{Qd}) \\
(\mathrm{ltr} / \mathrm{hr})\end{array}$ \\
\hline 1 & 2015 & 1.829 .735 & 365.947 \\
2 & 2016 & 2.105 .571 & 421.114 \\
3 & 2017 & 2.393 .076 & 478.615 \\
4 & 2018 & 2.692 .639 & 538.528 \\
5 & 2019 & 3.004 .663 & 600.933 \\
6 & 2020 & 3.329 .561 & 665.912 \\
7 & 2021 & 3.667 .758 & 733.552 \\
8 & 2022 & 4.019 .693 & 803.939 \\
9 & 2023 & 4.385 .819 & 877.164 \\
10 & 2024 & 4.766 .600 & 953.320 \\
\hline
\end{tabular}

Sumber: Hasil Pengolahan Data.

\subsubsection{Kebutuhan Air Rata-Rata.}

Kebutuhan air bersih rata-rata merupakan akumulasi dari kebutuhan air bersih domestik dan kebutuhan air bersih non domestik. Hasil perhitungan kebutuhan air bersih rata-rata seperti yang terdapat pada tabel berikut.

Tabel 7. Kebutuhan Air Rata-Rata Tahun 2015 - 2024.

\begin{tabular}{cccc}
\hline NO & Tahun & $\begin{array}{c}\text { Kebutuhan Air Rata-Rata } \\
(\mathrm{Qr})(\mathrm{ltr} / \mathrm{hr})\end{array}$ & $\begin{array}{c}\text { Kebutuhan Air Rata-Rata (Qr) } \\
\text { (ltr/dtk) }\end{array}$ \\
\hline 1 & 2015 & 2.195 .683 & 25,41 \\
2 & 2016 & 2.526 .685 & 29,24 \\
3 & 2017 & 2.871 .691 & 33,24 \\
4 & 2018 & 3.231 .167 & 37,40
\end{tabular}




\begin{tabular}{cccc}
5 & 2019 & 3.605 .596 & 41,73 \\
6 & 2020 & 3.995 .473 & 46,24 \\
7 & 2021 & 4.401 .309 & 50,94 \\
8 & 2022 & 4.823 .632 & 55,83 \\
9 & 2023 & 5.262 .983 & 60,91 \\
10 & 2024 & 5.719 .920 & 66,20 \\
\hline
\end{tabular}

Sumber: Hasil Pengolahan Data.

\subsection{Tingkat Kehilangan Air.}

Berdasarkan hal tersebut maka perkiraan kehilangan air untuk periode perencanaan seterusnya jika PDAM Tirta Meulaboh tidak melakukan pergantian jaringan pipa dapat dilihat pada tabel berikut.

Tabel 8. Kehilangan Air Tahun 2015 - 2024.

\begin{tabular}{cccccc}
\hline NO & Tahun & $\begin{array}{c}\text { Persentase } \\
\text { Kehilangan Air } \\
(\%)\end{array}$ & $\begin{array}{c}\text { Kapasitas } \\
\text { Produksi (ltr/dtk) }\end{array}$ & $\begin{array}{c}\text { Kapasitas } \\
\text { Produksi } \\
(\mathrm{ltr} / \mathrm{hr})\end{array}$ & $\begin{array}{c}\text { Kehilangan Air } \\
(\mathrm{ltr} / \mathrm{hr})\end{array}$ \\
\hline 1 & 2015 & 51 & 70 & 6.048 .000 & 3.084 .480 \\
2 & 2016 & 52 & 70 & 6.048 .000 & 3.144 .960 \\
3 & 2017 & 53 & 70 & 6.048 .000 & 3.205 .440 \\
4 & 2018 & 54 & 70 & 6.048 .000 & 3.265 .920 \\
5 & 2019 & 55 & 70 & 6.048 .000 & 3.326 .400 \\
6 & 2020 & 56 & 70 & 6.048 .000 & 3.386 .880 \\
7 & 2021 & 57 & 70 & 6.048 .000 & 3.447 .360 \\
8 & 2022 & 58 & 70 & 6.048 .000 & 3.507 .840 \\
9 & 2023 & 59 & 70 & 6.048 .000 & 3.568 .320 \\
10 & 2024 & 60 & 70 & 6.048 .000 & 3.628 .800 \\
\hline
\end{tabular}

Sumber: Hasil Pengolahan Data.

Berdasarkan perhitungan kehilangan air tersebut maka dapat dihitung volum air yang dapat dilayani kepada masyarakat Kota Meulaboh seperti yang terdapat pada tabel berikut ini.

Tabel 9 Volum Air Terlayani.

\begin{tabular}{cccccc}
\hline NO & Tahun & $\begin{array}{c}\text { Volume } \\
\text { Kebutuhan } \\
\text { Air (ltr/dtk) }\end{array}$ & $\begin{array}{c}\text { Volume Air } \\
\text { Terlayani } \\
\text { (ltr/dtk) }\end{array}$ & $\begin{array}{c}\text { Kekurangan/ } \\
\text { Kelebihan } \\
\text { Kapasitas Produksi } \\
\text { (ltr/dtk) }\end{array}$ & Keterangan \\
\hline 1 & 2015 & 25,41 & 34,30 & 8,89 & Mencukupi \\
2 & 2016 & 29,24 & 33,60 & 4,36 & Mencukupi \\
3 & 2017 & 33,24 & 32,90 & $(0,34)$ & Kekurangan \\
4 & 2018 & 37,40 & 32,20 & $(5,20)$ & Kekurangan \\
5 & 2019 & 41,73 & 31,50 & $(10,23)$ & Kekurangan \\
6 & 2020 & 46,24 & 30,80 & $(15,44)$ & Kekurangan \\
7 & 2021 & 50,94 & 30,10 & $(20,84)$ & Kekurangan \\
8 & 2022 & 55,83 & 29,40 & $(26,43)$ & Kekurangan \\
9 & 2023 & 60,91 & 28,70 & $(32,21)$ & Kekurangan \\
10 & 2024 & 66,20 & 28,00 & $(38,20)$ & Kekurangan \\
\hline
\end{tabular}

Sumber: Hasil Pengolahan Data.

\subsection{Strategi Penurunan Kehilangan Air.}

Menanggulangi kehilangan air baik pada unit produksi, pipa transmisi, dan pipa distribusi dan pipa sambungan rumah dapat dilakukan dengan merencanakan program-program rehabilitasi. 
Strategi untuk menurunkan kehilangan air adalah sebagai berikut :

1. Rehabilitasi di Unit Produksi/Instalasi.

Mengoptimalkan Standart Operasional Prosedur (SOP) kerja dan melaksanakan pengawasan/pengendalian fasilitas atau sistem yang ada.

2. Rehabilitasi jaringan pipa transmisi dan distribusi.

Dilakukan dengan kegiatan sebagai berikut:

a. Mengidentifikasikan kekurangan-kekurangan atau melengkapi kondisi jaringan yang ada/existing.

b. Memfungsikan kembali resorvoir yang tidak digunakan.

c. Melakukan analisa hidrolisis.

d. Mengganti pipa pada posisi atau titik-titik yang mempunyai angka kebocoran yang cukup tinggi.

e. Mengganti katup-katup pada titik-titik yang mempunyai tekanan yang besar.

f. Pemasangan alat ukur tekanan di beberapa titik kritis.

3. Rehabilitasi pipa retikulasi dan pipa sambungan rumah.

Dilakukan dengan kegiatan sebagai berikut:

a. Pemasangan meter distrist/bulk meter pada setiap 100 - 200 sambungan rumah pada satu zona tertentu.

b. Mengganti pipa pada titik-titik yang mempunyai angka kebocoran yang besar.

c. Mengganti katup-katup pada titik-titik yang mempunyai tekanan yang besar.

d. Pemasangan alat ukur tekanan di beberapa titik kritis.

e. Menyusun kembali pipa retikulasi di dalam jaringan perpipaan dengan sistem cabang.

f. Menyusun sistem pembayaran rekening air.

g. Melakukan pemeriksaan dan pengetesan antara jumlah air yang harus dibayar oleh pelanggan dengan meter air.

h. Mengganti meter air pelanggan yang sudah tua, tidak layak pakai atau rusak.

\section{KESIMPULAN}

Berdasarkan hasil dan analisis yang dilakukan dalam penelitian ini dapat disimpulkan beberapa hal sebagai berikut:

a. Berdasarkan Hasil perhitungan proyeksi jumlah penduduk Kota Meulaboh pada awal tahun rencana 2015 sebesar 58.645 jiwa dan akhir tahun rencana 2024 sebesar 71.894 jiwa dengan tingkat laju pertumbuhan penduduk sebesar 2,29\%.

b. Jumlah air yang terlayani untuk masyarakat Meulaboh di awal tahun rencana 2015 adalah sebesar 2.963.520 ltr/hari atau sebesar 34,3 ltr/dtk dan akhir tahun rencana 2024 sebesar 2.419.200 ltr/hari atau sebesar $28 \mathrm{ltr} / \mathrm{dtk}$.

c. Kebutuhan air masyarakat Kota Meulaboh pada hari maksimum di awal tahun rencana 2015 adalah sebesar 2.415.251ltr/hari dan akhir tahun rencana 2024 sebesar 6.291.912 ltr/hari.

d. Total kebutuhan air masyarakat Kota Meulaboh di awal tahun rencana 2015 adalah sebesar 5.499.731 ltr/hari atau sebesar 63,65 ltr/dtk dan akhir tahun rencana 2024 sebesar 9.920.712ltr/hari atau sebesar 114,82 ltr/dtk.

e. Langkah-langkah strategi rehabilitasi untuk menurunkan kehilangan air adalah Rehabilitasi di Unit Produksi/Instalasi, Rehabilitasi jaringan pipa transmisi dan distribusi dan Rehabilitasi pipa retikulasi dan pipa sambungan rumah 


\section{DAFTAR PUSTAKA}

Anonim, (2002), Keputusan Menteri Kesehatan Republik Indonesia No. 907/MENKES/SK/VII/2002, tentang Syarat-syarat dan Pengawasan Kualitas Air Minum.

Anonim, (1990), Peraturan Menteri Kesehatan Republik Indonesia No. 416/MENKES/PER/IX/1990, tentang Syarat-syarat dan Pengawasan Kualitas Air.

Anonim, (2010), Peraturan Menteri Kesehatan Republik Indonesia No. 492/MENKES/PER/IV/2010, tentang Persyaratan Kualitas Air Minum.

Agustina, D. V., (2007) Analisa Kinerja Sistem Distribusi Air Bersih PDAM Kecamatan Banyumanik Di Perumnas Banyumanik (Studi Kasus Perumnas Banyumanik Kel. Srondol Wetan) Semarang: Program Pasca Sarjana Magister Teknik Sipil-UNDIP.

Badan Pusat Statistik Aceh Barat, (2010), Aceh Barat Dalam Angka 2010.

Battermann. A (2001), A Strategy to Reduce Technical WaterLosses for Intermiten Water Supply Systems, Jerman

Bryson, John, (1988). “Strategic Planning for Public and Nonprofit Organizations”, Jossey Bass Publishers, San Francisco.

Djamal, Z. Irzal, Firdaus Ali, Riant Nugroho, Agus Kretarto, Andi Zulfikar, (2009), Penurunan Kehilangan Air: Pengalaman Jakarta setelah Kerjasama Pemerintah-Swasta 1998-2008, Jakarta: Badan Regulator PAM

Damanhuri, E., (1989), Pendekatan Sistem Dalam Pengendalian dan Pengoperasian Sistem Jaringan Distribusi Air Minum, Bandung: Jurusan Teknik Lingkungan FTSP-ITB.

Ferijanto, K., (2007), Kajian Kehilangan Air Pada Wilayah Kajian PDAM (Studi Kasus PDAM Kota Bandung), Bandung: Jurusan Teknik Lingkungan FTSP-ITB.

Husen. S.Hi, dan Hadi, W, (2009), Strategi Penurunan Kebocoran Di Sistem Distribusi Air Minum Kota Ternate (Studi Kasus PDAM Kota Ternate), Surabaya: Jurusan Teknik Lingkungan FTSP-ITS.

MWAC, (1999),Managing Water For AfricanCites Report And Strategy Background Paper.

Sari, F, K., (1999), Studi Kehilangan Air pada Jaringan Distribusi Air Minum PDAM Tasikmalaya Wilayah Situgede dan Bebedahan, ITB. Bandung.

Ristiarini, R., (1999), Studi Kehilangan Air pada Jaringan Distribusi Air Minum PDAM Tasikmalaya Wilayah Perum Kota Baru dan Bebedahan, ITB. Bandung.

Yepes, G., (1995), The World Bank Retrievedon July 7, 2004, Reduction of Unaccounted for Water,Best Practices (Gelijkwaardige pagina's) 